\title{
Effect of Sugarcane Trash Biochar on Enhancement of Soil Health and Sugarcane Productivity
}

\author{
P. Christy Nirmala Mary ${ }^{1 *}$ and R. Anitha ${ }^{2}$ \\ ${ }^{1}$ Department of Soils and Environment, Agricultural College and Research Institute, \\ Madurai -625104, India \\ ${ }^{2}$ Sugarcane Research Station, Cuddalore-607001, India \\ *Corresponding author
}

\section{A B S T R A C T}

\section{Keywords}

Sugarcane trash

Biochar - Carbon

Sequestration-

Climate change -

Cane yield

\section{Article Info}

Accepted:

28 October 2019

Available Online:

10 November 2019
In India, about 435.98 million tons of agro-residues are produced every year, out of which 313.62 million tons are surplus. These residues are either partially utilized or un-utilized due to various constraints ${ }^{[7]}$. Biochar and biochar-compost mixtures from different alternative organic sources have been proposed as an option for improving soil fertility, restoring degraded land and mitigating the emissions of greenhouse gasses associated with carbon sequestration and climate change. A pot culture experiment was carried out with seven treatments implying sugarcane trash biochar@ 2 tonnes and 4 tonnes /ha in combination with sugarcane trash compost, farm yard manure, press mud, sunhemp and $100 \%$ recommended dose of NPK. Results showed that the total N content of sugarcane was increased in cane $(0.32 \%)$, trash $(0.732 \%)$ and root $(0.458 \%)$. The total $\mathrm{P}$ content of cane was also improved to $0.120 \%$ in cane, trash to $0.271 \%$ and root to $0.094 \%$. The organic carbon and available nitrogen content of soil was enhanced to $0.298 \%$ and 211.53 $(\mathrm{kg} / \mathrm{ha})$ respectively in the treatment receiving $100 \%$ recommended NPK along with sunhemp@10 t/ha and biochar of 2t/ha. The same treatment resulted in a better improvement of germination of $91.33 \%$, tillering population of $173378 /$ ha, millable cane population of $127000.47 /$ ha, Leaf area of $464.22 \mathrm{~cm}^{2}$, plant height of $343.75 \mathrm{~cm}$, cane length of $216.67 \mathrm{~cm}$, cane girth of $2.46 \mathrm{~cm}$, root length of $41.17 \mathrm{~cm}$, internodes length of $10.42 \mathrm{~cm}$, number of nodes of $24.33 \mathrm{~cm}$, single cane weight of $1707.75 \mathrm{~g}$ and cane yield of 128.43t/ha. These findings lead us to suggest that further investigations are needed to assess the effect of biochar on plant and ratoon cane yields.

\section{Introduction}

India is the second largest country in sugarcane production in the world and it is the major source of sugar and varied raw materials for sugar industries and other allied by-product industries. Being a $\mathrm{C}_{4}$ crop, sugarcane had high potential of accumulating higher biomass up to 381 t/ha and sugar content up to $14.5 \%$. It also produces 10 to 12 $\mathrm{t}$ of dry leaves/ha during $5^{\text {th }}$ and $7^{\text {th }}$ months manually to carry out varied intercultural operations and to reduce the pest incidence like scales and mealy bugs ${ }^{[5]}$.Cane trash 
contains $68 \%$ of organic matter, $0.42 \%$ of nitrogen, $0.15 \%$ of phosphorous, $0.57 \%$ of potassium, $0.48 \%$ of calcium and $0.12 \%$ of magnesium. Besides it also contains 25.7, 2045 and 236.4 ppm of zinc, iron and manganese respectively.

Normally, trashes are burnt after detrashing usually results in environmental pollution since carbon is exerted into atmosphere as carbon dioxide. Conversion of sugarcane trash into biochar and using the char as a soil amendment is a nascent approach and suggested as an alternative to composting and burning ${ }^{[10]}$. But under the process of pyrolysis for biochar production, sugarcane trash is burnt in closed condition which gives a final product of carbon rich biochar. Sugarcane trash biochar is a carbon-rich by product resulting from the pyrolyzing biomass of sugarcane trash under high-temperature and low oxygen concentration. Various experiments were conducted in biochar and it shows that biochar improves soil water holding capacity, organic carbon and also reduces the net emission of carbon dioxide.

The pyrolysis conversion of waste biomass into biochar is attracting international attention as a soil amendment for improving soil quality and permanently sequestering carbon ${ }^{[4]}$.The use of biochar as soil amendment is proposed as a new approach to mitigate man-induced climate change along with improving soil productivity.

Research information on the use of biochar in Indian agriculture is scanty. Very few reports are available on production, characterization and use of sugarcane trash bio char as a soil amendment. The present paper explains the production and characterization of sugarcane trash biochar, to evaluate the effect of organic, inorganic fertilizers with sugarcane trash biochar on the physiological parameters, growth characters, yield of sugarcane and to optimize the level of biochar for maximizing the sugarcane yield and quality.

\section{Materials and Methods}

\section{Production of Sugarcane Trash Bio char:}

\section{CRIDA Model Kiln}

[11] developed a low-cost charring kiln by modifying oil drums at CRIDA, Hyderabad. A cylindrical metal oil drum (200 L capacity) with both sides intact was procured from local market and was modified for use as charring kiln. A square shaped hole of $16 \mathrm{~cm} \times 16 \mathrm{~cm}$ was made on the centre of top side of the drum for loading the crop residues. Sugarcane trashes were taken in an already dried condition and cut into pieces approximately 1 to $3 \mathrm{~cm}$ in size and placed inside the kiln.

The loaded kiln was placed on three stones (about $15 \mathrm{~cm}$ height) to facilitate air flow through the holes at the bottom. The stalks were ignited through the bottom holes. After the reduction in thickness of smoke, the metal sheet was placed partially on the top hole of the kiln to slow down the flow of air into the drum. This was to reduce the flow of oxygen so that the stalks were not burnt to ashes.

Whenever the amount of smoke increased, the cover was opened to allow more air flow. The sugarcane trash was subjected to three different periods of partial combustion viz. 13, 15 and 16 minutes. The kiln was allowed to burn until the fire became clear and produced a very thin blue smoke. At this stage, the kiln was ready to be sealed with clay. The metal sheet was placed over the top hole. Later, the kiln was transferred to a leveled surface. Clay was used to seal the bottom edges of the drum and also along the edges of the metal sheet used for covering the top hole. After cooling, the sealed clay was removed and the biochar was taken out from the kiln and weighed. 


\section{TNAU Model Kiln}

Sugarcane wastes were collected and tightly packed in Tamil Nadu Agricultural University model kiln by placing a metallic tube of 6 inch diameter at the centre of the drum. At the top, sugarcane trash are loaded, loose packs of the same is burnt and closed for a while to undergo pyrolysis process.

\section{Characterization of Sugarcane Trash Biochar}

The elemental composition of sugarcane trash biochar prepared by both kiln was analysed with total carbon analyser and ICP- OES by using standard analytical procedure.

\section{Pot Culture Experiment}

A pot culture experiment was conducted at Sugarcane Research Station, Cuddalore, Tamil Nadu, India during 2016-2017. The treatments include $\mathrm{T}_{1}-100 \%$ Recommended Dose of Fertilizer (RDF) (300:100:200 kg NPK/ha) Control ; $\mathrm{T}_{2}-100 \% \mathrm{RDF}+$ Biochar @ $2 \mathrm{t} / \mathrm{ha}$; $\mathrm{T}_{3}-100 \% \mathrm{RDF}+$ Biochar @ $4 \mathrm{t} / \mathrm{ha} ; \mathrm{T}_{4}-$ $100 \%$ RDF+ Biochar@ 2 t / ha + farm yard manure@10t/ha; T $-100 \%$ RDF + Biochar @ $2 \mathrm{t} / \mathrm{ha}+$ sugarcane trash compost @ $10 \mathrm{t}$ /ha ; $\mathrm{T}_{6}-100 \%$ RDF+ Biochar@ 2 t /ha+ pressmud@10 t /ha; $\mathrm{T}_{7}-100 \% \mathrm{RDF}+$ Biochar@2t/ha+ incorporation of sunhemp @ $10 \mathrm{t} / \mathrm{ha}$.

Air dried soil was filled in pots along with required quantity of organic manures and biochar and saturated for one day before planting. Experiment was conducted in Randomized Block Design with four replications using sugarcane cultivar $\mathrm{cv} \mathrm{CoC}$ (SC) 24. Pre germinated single bud seed canes were planted at the rate of five per pot. The pots were kept moist and fertilizer was added based on the treatment schedule.

\section{Growth and Physiological Parameters}

The plant height, Leaf area, stalk diameter, number of internodes, length of internodes, number of tillers, millable cane, single cane weight, root length and cane yield were recorded as per the standard procedure. Data on different parameters were subjected to statistical analysis and mean values were compared using LSD at 5\% level of significance ${ }^{[3]}$. The plant nitrogen, phosphorus and potassium content and soil available nitrogen and organic carbon content were analysed as per the standard analytical procedure.

\section{Results and Discussion}

\section{Characteristics of biochars}

The data on characteristics of biochar is presented in Table 1. The carbon content, C:N ratio and residual matter was higher in (41.19\%, 19.6:1 and 50.2\%) in biochar produced from CRIDA kiln method compared to TNAU kiln method $(37.82 \%, 14.16: 1$ and 49.25\%). According to Chun ${ }^{[1]}$, with an increase in pyrolytic temperature, the carbon content increases while the oxygen and hydrogen content decreases indicating an increasing degree of carbonization of chars.

Comparing the production methods, the total nitrogen, $\mathrm{P}, \mathrm{Ca}$ and $\mathrm{Mg}$ contents were higher for biochar produced from CRIDA kiln method $(2.9,2.4,18.3$ and $5.9 \mathrm{~g} / \mathrm{kg})$ than bio char produced from TNAU model kiln method. ${ }^{[2]}$ reported that biochar produced at higher temperature showed nutrient depletion due to volatilization. Biochar produced by CRIDA kiln method showed higher potassium content $(35.2 \mathrm{~g} / \mathrm{kg})$ than TNAU model kiln method $(33.2 \mathrm{~g} / \mathrm{kg})$. The $\mathrm{pH}$ was almost similar and the EC content was $9.6 \mathrm{dSm}^{-1}$ and $6.3 \mathrm{dSm}^{-1}$ respectively in biochar produced from CRIDA and TNAU model kiln. The mobile matter, ash content, final moisture 
content and elemental composition were not much varied.

Effect of sugarcane trash biochar on the Growth parameters of sugarcane

\section{Germination}

Appreciable difference in germination was observed among the different treatments (Table.2.). The germination was maximum of $91.33 \%$ in the treatment $\left(\mathrm{T}_{7}\right)$ receiving $100 \%$ NPK, biochar@2t/ha with sunhemp@10 t/ha and there was no significant difference between the treatments regarding germination.

\section{Tiller population}

The tiller population was maximum (173378.67 / ha) in the treatment receiving $100 \%$ NPK, biochar @2t/ha with sunhemp@10 t/ha 7, followed by planting the setts in $100 \%$ RDF with biochar @2t/ha +PM @ 10t/ha (170754.00 tillers / ha). The gradual reduction of tiller population (158399.33 /ha) was with $100 \%$ RDF and biochar@ 4 t /ha. In biochar applied treatments, organic matter was very low and because of the high carbon content, the nutrients may be immobilized and prevented the immediate availability of nutrients for the growth of the sugarcane.

\section{Millable cane population}

The millable population was maximum with $1,27,470 /$ ha in the treatment received $100 \%$ NPK with biochar@2t/ha+sunhemp@10t/ha. Application of $100 \%$ RDF with biochar @ 4t/ha produced $1,19,590$ canes/ha. The treatments differ significantly in their cane production ability. The application of $100 \%$ RDF + biochar @2t/ha and $100 \%$ RDF. biochar@2 t/ha +FYM @10 t/ha produced $1,14,990$ and 1,15,200 canes/ha respectively.

\section{Leaf characteristics}

The data regarding the effects of treatments on leaf length, leaf width and leaf area are presented in Table 2. The leaf length was observed to be maximum $(143.50 \mathrm{~cm})$ in the treatment receiving $100 \% \mathrm{RDF}$ with biochar 2 t/ha and sunhemp @ 10t/ ha followed by $\mathrm{T}_{5}$ $(138.00 \mathrm{~cm})$ and $\mathrm{T}_{4}(124.80 \mathrm{~cm})$. The minimum leaf length of $85.75 \mathrm{~cm}$ was observed in the treatment with $100 \%$ RDF. Application of $100 \%$ RDF and sugarcane trash biochar@ $4 \mathrm{t} / \mathrm{ha}$ registered the leaf width of $6.1 \mathrm{~cm}$ and minimum was with the treatment $\mathrm{T}_{4}$. The highest leaf area of 464.22 $\mathrm{cm}^{2}$ was noticed in the treatment receiving $100 \%$ RDF, biochar @2 t/ha and sunhemp @ 10 t/ha.

\section{Effect of sugarcane trash biochar on Plant growth and yield attributes characters}

The treatments had significant effect on sugarcane plant height and yield attributes. The highest plant height $(343.75 \mathrm{~cm})$, cane length $(216.67 \mathrm{~cm})$, inter node length $(10.42$ $\mathrm{cm})$, number of internodes (24.33), cane girth $(2.46 \mathrm{~cm})$, single cane weight $(1717.75 \mathrm{~g})$ and cane yield (128.43 t/ha) was observed in the treatment receiving $100 \% \mathrm{RDF}$, biochar @2t/ha and sunhemp@10t/ha $\left(\mathrm{T}_{7}\right)$ (Table 4). The increased cane yield was attributed to the higher germination, increased number of tillers, more number of millable canes which ultimately increased the cane yield. 
Table.1 Characteristics of sugarcane trash biochar

\begin{tabular}{|c|c|c|c|}
\hline $\begin{array}{c}\text { S. } \\
\text { No. }\end{array}$ & Particulars & $\begin{array}{c}\text { Sugarcane trash biochar- } \\
\text { CRIDA model kiln }\end{array}$ & $\begin{array}{c}\text { Sugarcane trash biochar- } \\
\text { TNAU model kiln }\end{array}$ \\
\hline 1. & Carbon & 41.19 & 37.82 \\
\hline 2. & Hydrogen & 4.02 & 4.65 \\
\hline 3. & Nitrogen & 2.1 & 2.67 \\
\hline 4. & C: $\mathrm{N} \mathrm{ratio}$ & $19.6: 1$ & $14.16: 1$ \\
\hline 5. & $\mathrm{pH}$ & 9.0 & 9.6 \\
\hline 6. & EC(dSm $\left.{ }^{-1}\right)$ & 9.6 & 6.3 \\
\hline 7. & Mobile matter $(\%)$ & 31.2 & 36.2 \\
\hline 8. & Ash content $(\%)$ & 3.00 & 3.62 \\
\hline 9. & Residual matter $(\%)$ & 50.2 & 49.25 \\
\hline 10. & Final moisture content & 3.5 & 4.00 \\
\hline & & Elemental composition (g/Kg $)$ & \\
\hline 1. & Nitrogen & 2.9 & 2.2 \\
\hline 2. & Sulphur & 0.09 & 0.1 \\
\hline 3. & Phosphorus & 2.4 & 2.2 \\
\hline 4. & Potassium & 33.2 & 35.2 \\
\hline 5. & Calcium & 18.3 & 17.5 \\
\hline 6. & Magnesium & 5.9 & 5.2 \\
\hline
\end{tabular}

Table.2 Effect of sugarcane trash biochar and different organics on sugarcane growth characters

\begin{tabular}{|c|c|c|c|c|c|c|}
\hline Treatments & $\begin{array}{c}\text { Germina } \\
\text { tion } \\
(\%)\end{array}$ & $\begin{array}{c}\text { Tiller } \\
\text { population } \\
\text { per ha }\end{array}$ & $\begin{array}{c}\text { Millable } \\
\text { Cane } \\
\text { ('000/ha) }\end{array}$ & $\begin{array}{l}\text { Leaf } \\
\text { length } \\
(\mathrm{cm})\end{array}$ & $\begin{array}{c}\text { Leaf } \\
\text { width } \\
\text { (cm) }\end{array}$ & $\begin{array}{l}\text { Leaf } \\
\text { Area } \\
\left(\mathrm{cm}^{2}\right)\end{array}$ \\
\hline $\mathrm{T}_{1} \mathbf{1 0 0} \% \mathrm{RDF}$ & 57.16 & 135833.33 & 105.74 & 85.75 & 5.3 & 294.05 \\
\hline $\mathbf{T}_{2-} \mathrm{T}_{1}+$ biochar @ 2t/ha & 75.91 & 149570.33 & 114.99 & 97.50 & 5.4 & 340.64 \\
\hline$T_{3-} T_{1+}$ biochar @ 4t/ha & 75.25 & 158399.33 & 119.59 & 87.50 & 6.1 & 345.34 \\
\hline $\begin{array}{c}T_{4-} T_{1+} \text { biochar @ 2t/ha + } \\
\text { FYM @10t/ha }\end{array}$ & 79.83 & 160045.33 & 115.20 & 124.80 & 4.5 & 363.36 \\
\hline $\begin{array}{l}T_{5-} T_{1+} \text { biochar } @ 2 t / h a+ \\
\text { S.trash compost } @ 10 \text { t/ha }\end{array}$ & 87.75 & 150970.67 & 118.47 & 138.00 & 5.1 & 455.36 \\
\hline $\begin{array}{c}T_{6-} T_{1+} \text { biochar @ } 2 t / h a+P M \\
@ 10 t / h a\end{array}$ & 90.16 & 170754.00 & 122.93 & 96.50 & 5.6 & 349.64 \\
\hline $\begin{array}{c}T_{7-} T_{1+} \text { biochar } \\
@ 2 t / h a+\text { sunhemp@10t/ha }\end{array}$ & 91.33 & 173378.67 & 127.47 & 143.50 & 5.0 & 464.22 \\
\hline C. $D(P=0.05)$ & NS & NS & 6.83 & 25.51 & 0.54 & 112.43 \\
\hline
\end{tabular}


Table.3 Effect of sugarcane trash biochar and different organics on sugarcane growth characters

\begin{tabular}{|c|c|c|c|c|c|c|c|}
\hline Treatments & $\begin{array}{c}\text { Plant } \\
\text { height } \\
(\mathrm{cm})\end{array}$ & $\begin{array}{c}\text { Cane } \\
\text { length } \\
(\mathrm{cm})\end{array}$ & $\begin{array}{l}\text { Internode } \\
\text { length }(\mathrm{cm})\end{array}$ & $\begin{array}{l}\text { Number } \\
\text { of nodes }\end{array}$ & $\begin{array}{l}\text { Cane } \\
\text { girth } \\
\text { (cm) }\end{array}$ & $\begin{array}{c}\text { Single } \\
\text { cane } \\
\text { weight } \\
\text { (g) }\end{array}$ & $\begin{array}{c}\text { Cane } \\
\text { Yield } \\
\text { t/ha }\end{array}$ \\
\hline $\mathrm{T}_{1-} 100 \% \mathrm{RDF}$ & 292.75 & 165.42 & 8.76 & 17.67 & 1.39 & 891.25 & 117.12 \\
\hline $\mathrm{T}_{2-} \mathrm{T}_{1}+\mathrm{biochar} @ 2 \mathrm{t} / \mathrm{ha}$ & 303.83 & 182.67 & 10.31 & 22.33 & 1.47 & 1339.00 & 12.32 \\
\hline$T_{3-} T_{1+}$ biochar @ 4t/ha & 339.42 & 188.16 & 10.74 & 20.33 & 1.68 & 997.75 & 124.05 \\
\hline $\begin{array}{c}T_{4-} T_{1+} \text { biochar @2t/ha + } \\
\text { FYM @10t/ha }\end{array}$ & 331.04 & 195.08 & 9.40 & 20.25 & 1.65 & 1237.00 & 119.20 \\
\hline $\begin{array}{l}T_{5-} T_{1+} \text { biochar @ 2t/hat } \\
\text { S.trash compost@10 t/ha }\end{array}$ & 326.21 & 190.50 & 9.56 & 21.67 & 1.92 & 1079.50 & 122.40 \\
\hline $\begin{array}{c}T_{6-} T_{1+} \text { biochar @2t/ha } \\
+P M @ 10 t / h a\end{array}$ & 335.25 & 208.83 & 10.15 & 23.25 & 2.44 & 1343.50 & 126.37 \\
\hline $\begin{array}{c}\mathrm{T}_{7-} \mathrm{T}_{1+} \text { biochar } \\
\text { @2t/ha+sunhemp@10t/ha }\end{array}$ & 343.75 & 216.67 & 10.42 & 24.33 & 2.46 & 1707.75 & 128.43 \\
\hline C. $D(P=0.05)$ & 53.29 & 20.41 & 1.18 & 2.56 & 0.51 & 278.61 & 12.54 \\
\hline
\end{tabular}

Table.4 Effect of sugarcane trash bio char on total sugarcane nutrient content

\begin{tabular}{|c|c|c|c|c|c|c|c|c|c|}
\hline \multirow[t]{2}{*}{ Treatments } & \multicolumn{3}{|c|}{ Total N (\%) } & \multicolumn{3}{|c|}{ Total P(\%) } & \multicolumn{3}{|c|}{ Total K (\%) } \\
\hline & Cane & trash & Roots & Cane & trash & Roots & Cane & trash & Roots \\
\hline $\mathrm{T}_{1-} 100 \% \mathrm{RDF}$ & 0.20 & 0.612 & 0.415 & 0.105 & 0.157 & 0.0075 & 0.384 & 0.791 & 0.065 \\
\hline $\mathrm{T}_{2-} \mathrm{T}_{1}+$ biochar@2t/ha & 0.23 & 0.614 & 0.402 & 0.105 & 0.165 & 0.0888 & 0.462 & 0.819 & 0.075 \\
\hline $\mathrm{T}_{3-} \mathrm{T}_{1+}$ biochar @4t/ha & 0.28 & 0.634 & 0.427 & 0.103 & 0.171 & 0.0780 & 0.545 & 0.825 & 0.077 \\
\hline $\begin{array}{c}\mathrm{T}_{4-} \mathrm{T}_{1+} \text { biochar@2t/ha + } \\
\text { FYM @ 10t/ha }\end{array}$ & 0.28 & 0.618 & 0.427 & 0.128 & 0.182 & 0.0810 & 0.572 & 0.821 & 0.085 \\
\hline $\begin{array}{l}\mathrm{T}_{5-} \mathrm{T}_{1+} \text { biochar @2t/ha+ } \\
\text { S.trash compost@10t/ha }\end{array}$ & 0.31 & 0.623 & 0.430 & 0.118 & 0.170 & 0.0892 & 0.572 & 0.824 & 0.078 \\
\hline $\begin{array}{c}\mathrm{T}_{6-} \mathrm{T}_{1+} \text { biochar @2t/ha } \\
+\mathrm{PM} @ 10 \mathrm{t} / \mathrm{ha}\end{array}$ & 0.26 & 0.619 & 0.432 & 0.115 & 0.131 & 0.0865 & 0.560 & 0.787 & 0.082 \\
\hline $\begin{array}{c}\mathrm{T}_{7-} \mathrm{T}_{1+} \text { biochar } \\
@ 2 \mathrm{t} / \mathrm{ha}+\text { sunhemp } @ 10 \mathrm{t} / \mathrm{ha}\end{array}$ & 0.32 & 0.732 & 0.458 & 0.120 & 0.271 & 0.0940 & 0.584 & 0.842 & 0.087 \\
\hline SE.d & NS & 0.02 & 0.01 & 0.01 & NS & NS & 0.02 & NS & NS \\
\hline C. $\mathrm{D}(\mathrm{P}=0.05)$ & & 0.06 & 0.02 & 0.02 & & & 0.05 & & \\
\hline
\end{tabular}


Table.5 Effect of organics, in organics and sugarcane trash bio char on soil organic carbon content $(\%)$ and available nitrogen $(\mathrm{kg} / \mathrm{ha})$

\begin{tabular}{|c|c|c|}
\hline Treatments & $\begin{array}{c}\text { Organic carbon } \\
(\%)\end{array}$ & $\begin{array}{c}\text { Available Nitrogen } \\
\text { (kg/ha.) }\end{array}$ \\
\hline $\mathrm{T}_{1-} \mathbf{1 0 0} \% \mathrm{RDF}$ & 0.050 & 121.83 \\
\hline $\mathbf{T}_{2-} \mathbf{T}_{1}+$ biochar @2t/ha & 0.245 & 190.73 \\
\hline $\mathbf{T}_{3-} \mathbf{T}_{1+}$ biochar @4t/ha & 0.028 & 140.00 \\
\hline$T_{4-} T_{1+}$ biochar @2t/ha + FYM @10t/ha & 0.183 & 142.50 \\
\hline $\begin{array}{c}T_{5-} T_{1+} \text { biochar @2t/ha+ S.trash compost @10 } \\
\text { t/ha }\end{array}$ & 0.273 & 164.26 \\
\hline$T_{6-} T_{1+}$ biochar @2t/ha +PM @10t/ha & 0.291 & 152.00 \\
\hline$T_{7-} T_{1+}$ biochar @2t/ha+sunhemp@10t/ha & 0.298 & 211.53 \\
\hline C. $\mathbf{D}(\mathbf{P}=\mathbf{0 . 0 5})$ & 0.05 & 25.36 \\
\hline
\end{tabular}

Table.6 Effect of organics, inorganics and sugarcane trash biochar on root growth of sugarcane under pot experiment

\begin{tabular}{|c|c|c|c|}
\hline Treatments & $\begin{array}{l}\text { Root length } \\
(\mathbf{c m})\end{array}$ & $\begin{array}{l}\text { Root fresh } \\
\text { weight }(g)\end{array}$ & $\begin{array}{r}\text { Root dry } \\
\text { weight (g) }\end{array}$ \\
\hline $\mathrm{T}_{1-} 100 \% \mathrm{RDF}$ & 25.67 & 121 & 34 \\
\hline$T_{2--} T_{1}+$ biochar @2t/ha & 30.08 & 143 & 40 \\
\hline$T_{3-} T_{1+}$ biochar @4t/ha & 33.25 & 156 & 63 \\
\hline$T_{4-} T_{1+}$ biochar @2t/ha + FYM @ 10t/ha & 31.25 & 149 & 40 \\
\hline $\begin{array}{c}T_{5-} T_{1+} \text { biochar @ 2t/ha+ S.trash } \\
\text { compost } @ 10 \text { t/ha }\end{array}$ & 36.00 & 131 & 37 \\
\hline $\mathrm{T}_{6-} \mathrm{T}_{1+}$ biochar @2t/ha +PM @10t/ha & 31.75 & 168 & 64 \\
\hline$T_{7-} T_{1+}$ biochar @2t/ha+sunhemp@10t/ha & 41.17 & 176 & 72 \\
\hline C. $\mathbf{D}(\mathbf{P}=\mathbf{0 . 0 5})$ & 8.04 & NS & 15.57 \\
\hline
\end{tabular}


Fig.1

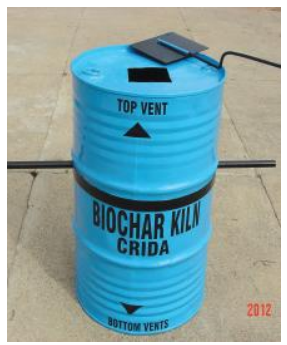

Fig.2

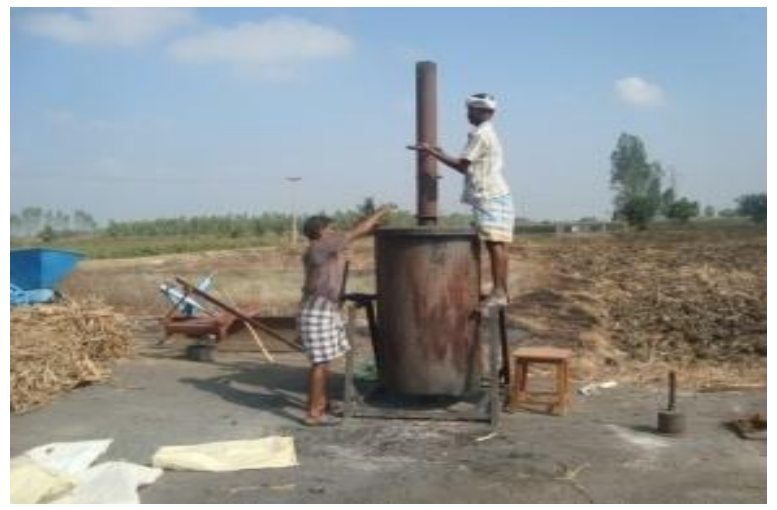

Fig.3

\section{Pot culture studies}

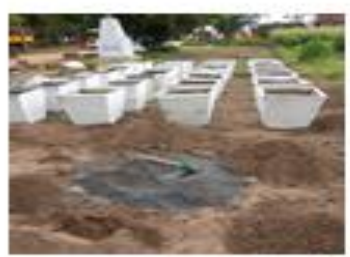

Mixing of biochar with soil and manures

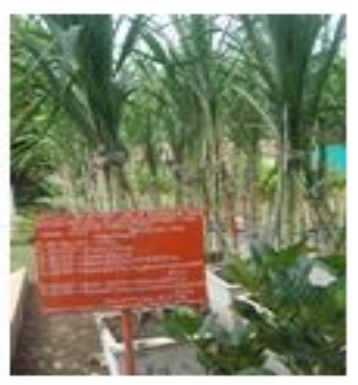

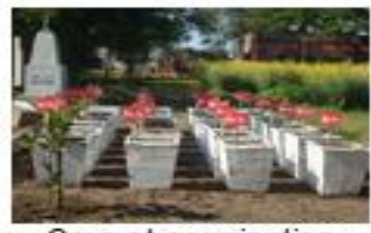

Crop at germination phase

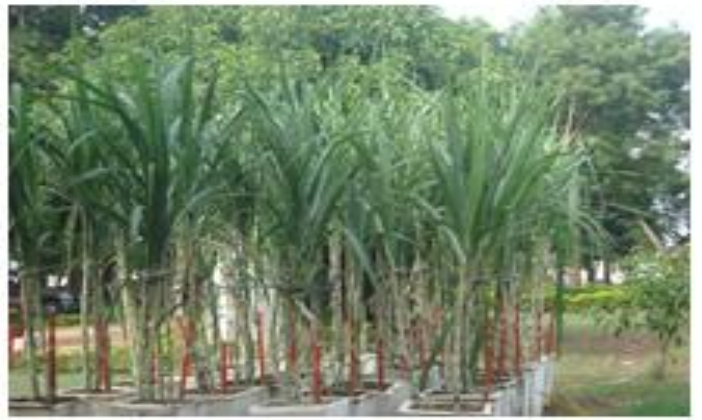

Grand growth phase 


\section{Fig.4}
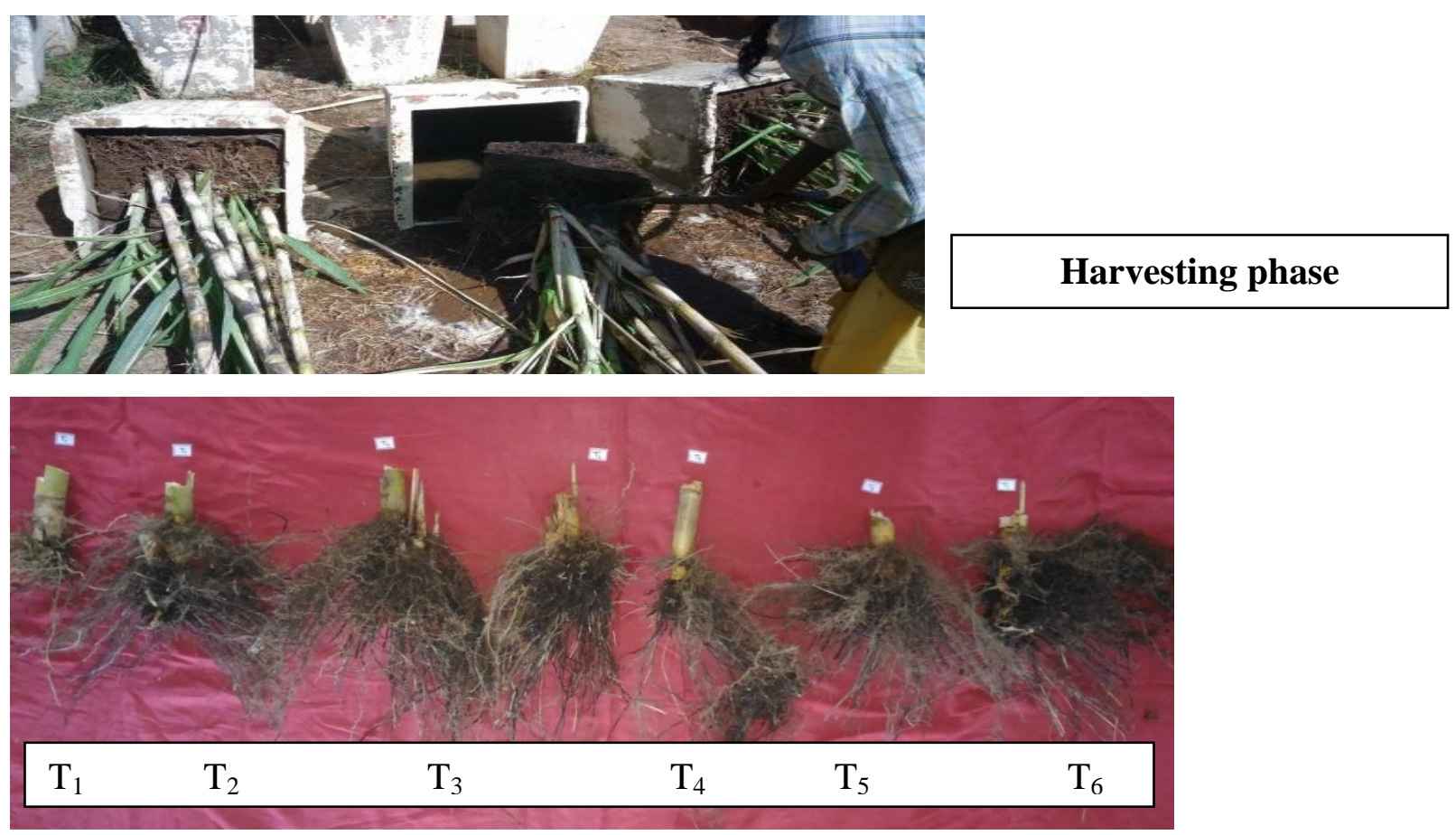

The economic yield is determined by the capability of plant to produce photosynthesis and their distribution to economically valuable plant parts. ${ }^{[9]}$ stated that application of biochar prepared from wheat straw in combination with recommended doses of NPK significantly increased the yield of maize by $23 \% .{ }^{[6]}$ stated that the addition of biochar in a nutrient-poor, slightly acidic and sandy loam soil had little effect on wheat yield in the absence of mineral fertilization but when it is applied along with the of mineral fertilizers produced 20-30\% more yield than application of mineral fertilizer alone.

Effect of bio char on the plant nutrient content

Significant difference in the cane phosphorus and potassium content was observed due to the application of sugarcane trash bio char, fertilizers and organic manures. Application of sugarcane trash bio char @ 2t ha ${ }^{-1}, 100 \%$ Recommended Dose of Fertilizers and organic manures significantly increased the cane, trash and root's nitrogen, phosphorus and potassium content and the application of $100 \%$ recommended dose of fertilizers alone recorded the minimum NPK content in cane, trash and roots. There was no significant difference in cane total $\mathrm{N}$, trash total $\mathrm{P}$, root total $\mathrm{P}$, total trash $\mathrm{k}$ and root $\mathrm{K}$.

\section{Effect of Sugarcane Trash Biochar on Soil Available Nitrogen and Organic Carbon Content}

\section{Organic Carbon}

The organic carbon content of the soil was increased significantly to 0.298 per cent in the treatment receiving $100 \% \mathrm{RDF}$, sunhemp @10 t/ha and sugarcane trash biochar @ 2t/ha.

This could be due to the effect of sugarcane trash biochar and organic manures excelled along with inorganic fertilizers at later stage and also due to the release of organic acids 
and compounds into the soil. The organic carbon content availability was maximum at $20 \mathrm{~cm}$ depth than other depth of soil layers which can improve the soil properties such as aggregation, aeration, permeability, water holding capacity, hormonal activity, microbial growth, organic matter mineralization solubilisation and availability of microelements ${ }^{[12]}{ }^{[8]}$ reported that biochar exerted considerable positive influence on the accumulation of soil organic matter. The residual soil organic matter was in increasing trend with the level of biochar.

\section{Available Nitrogen}

From the results (Table. 5), it could be noticed that additional rates of sugarcane trash biochar had a significant effect on soil available nitrogen content in soil. Generally, addition of biochar jointly with $\mathrm{N}, \mathrm{P}$ and $\mathrm{K}$ improves the soil fertility status.

The highest available nitrogen concentration in the surface layer was $211.53 \mathrm{~kg} / \mathrm{ha}$. in the $100 \%$ NPK with suagarcane trash biochar @2 t/ha and sun hemp @10 t/ha treatment when compared to application of $100 \% \mathrm{RDF}$ alone.

Application of sugarcane trash compost promoted significant accumulation of available nitrogen content.

\section{Effect of Sugarcane Trash Biochar on Root Growth of Sugarcane (Table.6)}

Application of sugarcane trash biochar @ 2t/ha with organic and inorganic application on increased root length $(41.17 \mathrm{~cm})$, root fresh weight (176 g) and root dry weight (72 g) may be advocated to sustain overall cane productivity.

These findings lead us to suggest that further investigations are needed to assess the complete effect of biochar on the economic feasibility in application of sugarcane trash biochar on plant and ratoon crops.

\section{References}

Chun, Y., Sheng, G., Chiou, C. T. and Xing, B. 2004. Compositions and sorptive properties of crop residue-derived chars. Environ. Sci. Technol. 38: 4649-4655

De Luca, T. H., MacKenzie, M. D. and Gundale, M. J. 2009. Biochar effects on soil nutrient transformations. In: Lehmann, J. and Joseph, S. (eds), Biochar for Environmental Management: Science and Technology. Earthscan, London, pp. 251-270.

Gomez, K.A and A.A. Gomez, 1984. Statistical procedures for agricultural research (2nd Ed.). A Wiley Interscience Publication, NY, USA.

Hossain,M.K., V.Strezov, K.Y.Chan and P.F.Nelson. 2010. Agronomic properties of waste water sludge biochar and bioavailablity of metals in production of cherry tomato (Lycopersicon esculentum). Chemosphere 78: 1167-1171.

IARI (Indian Agricultural Research Institute) 2012. Crop Residues Management with Conservation Agriculture: Potential, Constraints and Policy Needs. Indian Agricultural Research Institute, New Delhi, 32 p.

Lori A. Biederman and W.Stanley Harpole. 2013. Biochar and its effect on plant productivity and nutrient cycling: a meta- analysis. GCB Bioenergy. 5:202-214. 
Murali, S., Shrivastava, R. and Saxena, M. 2010. Greenhouse gas emissions from open field burning of agricultural residues in India. J. Environ. Sci. Eng. 52(4): 277-84

Naseem Khan, Zahir Shah, Nazeer Ahmed, Saeed Ahmad, Nasir Mehmood and Muham mad Junaid.2013. Effect of integrated use of biochar, FYM and nitrogen fertilizer on soil organic fertility. Pure Appl.Bio, 2(2): 42-47.

Purakayastha, T. J. 2010. Effect of biochar on yield of different crops. Annual Report 2010-2011. Indian Agricultural Research Institute, New Delhi, pp. 55.

Srinivasarao, Ch., Gopinath, K. A., Venkatesh, G., Dubey, A. K., Wakudkar, H., Purakayastha, T. J., Pathak, H., Jha, P., Lakaria, B. L., Rajkhowa, D. J., Mandal, S., Jeyaraman,S., Venkateswarlu, B. and Sikka, A. K. 2013. Use of Biochar for Soil Health Management and
Greenhouse Gas Mitigation in India: Potential and Constraints. Central Research Institute for Dryland Agriculture, Hyderabad, Andhra Pradesh, 51p

Venkatesh, G., Korwar, G. R., Venkateswarlu, B., Gopinath, K. A., Mandal, U.K., Srinivasarao, Ch. and Grover, M. T. 2010. Preliminary studies on conversion of maize stalks into biochar for terrestrial sequestration of carbon in rainfed agriculture. In: National Symposium on Climate Change and Rainfed Agriculture, 18-20 February, 2010, Central Research Institute for Dryland Agriculture, Hyderabad, pp 388-391.

Venkatakrishnan, D., \& Ravichandran, M. (2012). Effect of Integrated Nutrient Management on SugarcaneYield and Soil Fertility on an Ultic Haplustalf. Journal of the Indian Society of Soil Science, 60 (1), 74-78.

\section{How to cite this article:}

Christy Nirmala Mary, P. and Anitha, R. 2019. Effect of Sugarcane Trash Biochar on Enhancement of Soil Health and Sugarcane Productivity. Int.J.Curr.Microbiol.App.Sci. 8(11): 2650-2660. doi: https://doi.org/10.20546/ijcmas.2019.811.304 